Інна СРАСТОВА-МИХАЛУСЬ, orcid.org/0000-0003-2350-6082 кандидат педагогічних наук,

доиент кафедри авіаційної англійської мови Харківського начіонального університету Повітряних Сил імені Івана Кожедуба (Харків, Україна) innaem28@gmail.com

Дiана
orcid.org/0000-0002
кандидат педагог
доцент кафедри іноземних мов та міжкультурної
Харківського національного економічного університету імені Семе
(Харків, Україна) sundian
МІЖКУЛЬТУРНИЙ АСПЕКТ ФОРМУВАННЯ
ФЕСІЙНО-ОРІЕНТОВАНОЇ ІНОЗЕМНОЇ МОВИ

Статтю присвячено розгляду міжкультурного аспекту формування медіативної компетентності як одного з інструментів управління проблемами, які виникають під час професійної діяльності, а також як засобу запобігання та вирішення міжкультурних конфліктів.

Проаналізовано понятійний зміст терміна «медіація», який на сучасному етапі розвитку науки розглядається як вербальна діяльність, щзо передбачає письмові або усні дї медіатора, а також соиіокультурні вміння і вміння інтерпретування та інтеракиії, щзо забезпечують комунікацію між людьми, не здатними з будь-яких причин спілкуватися безпосередньо один з одним. Надано характеристику ролі медіатора в мультикультурному середовищі, основною місією якого є налагодження міжкультурної комунікації, особистісної комунікації та взаєморозуміння. Медіатор розглядається як фахівецьь, щзо пов'язаний із процесом передачі концептуальної та культурологічної інформації, релевантної для даної ситуації спілкування. Зазначено необхідність і важливість толерантності як професійно значущої якості медіатора, щцо дозволяє налагодити особистісну та міжкультурну комунікацію, а також взаєморозуміння.

Підкреслюється важливість володіння фахівиями знаннями про національні професійні реаліі, вміння визначати їх місце та значущість в ієрархї иінностей у глобальному співтоваристві, щзо передбачає розгляд терміна «глокалізачія», який трактується як трансформаџія глобалізаційних процесів з урахуванням локальної специифіки та охоплює не тільки інтернаціональне і транснаціональне, але й також транскультурне та транслокальне. Зазначається необхідність використання на заняттях з професійно-орієнтованої іноземної мови етнорегіонального матеріалу, сталих елементів культури, щзо сприяють розкриттю змісту етнокультурних традицій, уведення актуального соціокультурного матеріалу.

Представлено низку дидактичних засобів, які, на думку авторів, сприяють ефективному формуванню міжкультурної медіативної компетентності.

Ключові слова: медіативна компетентність, глокалізація, медіатор, міжкультурна комунікація, толерантність, комунікативна компетентість, дидактичні засоби.

Inna YERASTOVA-MYKHALUS, orcid.org/0000-0003-2350-6082

Candidate of Pedagogical Sciences, Associate Professor at the Aviation English Department Ivan Kozhedub Kharkiv National Air Force University (Kharkiv,Ukraine) innaem28@gmail.com

Diana TSYPINA,
orcid.org/0000-0002-5706-2793
Candidate of Pedagogical Sciences,
Associate Professor at the Department for Foreign Languages
and Intercultural Communication
Simon Kuznets Kharkiv National University of Economics
(Kharkiv, Ukraine) sundian@ukr.net




\section{INTERCULTURAL ASPECT OF THE FORMATION OF MEDIATIVE COMPETENCE IN THE PROCESS OF LEARNING PROFESSIONALLY ORIENTED FOREIGN LANGUAGE}

The article is devoted to the consideration of the intercultural aspect of the formation of mediative competence as one of the tools for managing problems that arise during professional activities, as well as a means of preventing and resolving intercultural conflicts.

The conceptual meaning of the term «mediation», which at the present stage of science development is considered as a verbal activity involving written or oral actions of a mediator, as well as social and cultural skills of interpretation and interaction that provide communication between people unable communicate directly with each other for any reason, is analyzed. The characterization of the role of a mediator in a multicultural environment whose main mission is to establish intercultural communication, personal communication and mutual understanding is given. A mediator is observed as a specialist involved in the process of conveying conceptual and cultural information relevant to a given communicative situation. The necessity and importance of tolerance as a professionally significant quality of a mediator, which allows establishing personal and intercultural communication, as well as mutual understanding, is noted.

The importance of specialists' knowledge of national professional realities, the ability to determine their place and importance in the hierarchy of values in the global community, which presupposes the consideration of the term "glocalization", which is interpreted as a transformation of globalization processes taking into account local specifics and covers not only the international and transnational, but also transcultural and translocal, are emphasized. A need to use ethnic and regional material, permanent elements of culture that contribute to the disclosure of the content of ethnocultural traditions, the introduction of relevant social and cultural material during professionally-oriented foreign language classes.

A number of didactic tools, which, in authors'opinion, contribute to the effective formation of intercultural mediation competence, are presented.

Key words: mediator competence, glocalization, mediator, intercultural communication, tolerance, communicative competence, didactic tools.

Постановка проблеми. Сучасний стан суспільства потребує необхідності володіння фахівцями здатністю 3 подолання можливих конфліктних або кризових ситуацій, що виникають на робочому місці. 3 цієї причини необхідною $\epsilon$ акцентуація уваги на превентивному виявленні проблем, вирішенні конфліктів на ранніх стадіях та недопущення їх загострення. Глобалізація суспільства $€$ важливим чинником того, що медіативні процедури стають одним з ефективних інструментів управління не тільки між- та внутрішньокорпоративними спорами та проблемами, але й запобігання та вирішення міжкультурних конфліктів.

Аналіз досліджень. Дослідження медіації в навчальному процесі входить у коло наукових зацікавлень А. Я. Анцупова, М. Байрама, Р. Тафта, А. Г. Чернишенка, Л. П. Шустової та становить значний дослідницький інтерес О. В. Козлової, Г. Пенса, В. Смирнової, О. Смислової та інших. Разом із тим теоретичний аналіз наукових праць свідчить, що міжкультурний аспект формування медіативної компетентності в процесі вивчення професійно-орієнтованої іноземної мови в закладах вищої освіти ще не був предметно досліджений у сучасній вітчизняній педагогічній науці.

Мета статті полягає в аналізі міжкультурного аспекту формування медіативної компетентності в процесі вивчення професійно-орієнтованої іноземної мови в закладах вищої освіти та у виокремленні його складників.
Виклад основного матеріалу. 3 метою дослідження питання міжкультурного аспекту медіації слід 3'ясувати понятійний зміст самого терміна «медіація», оскільки розуміння цього терміна у 2016 році (Council of Europe, 2016) зазнало суттєвих змін у порівнянні 3 його загальноєвропейським трактуванням у 2001 році (Council of Europe, 2001). У загальноєвропейському контексті термін «медіація» означав вербальну діяльність, що передбачає письмові або усні дії медіатора, які забезпечують комунікацію між людьми, не здатними 3 будь-яких причин спілкуватися безпосередньо один з одним (Council of Europe, 2001: 87). До засобів медіативної діяльності відносилися парафраз, узагальнення інформації, а також письмовий та усний переклад.

За оновлення загальноєвропейських дескрипторів та оціночних шкал у 2016 році понятійний зміст терміна «медіація» розширюється за рахунок додання до інструментарію медіатора, окрім двомовних умінь, також соціокультурних умінь i вмінь інтерпретування та інтеракції. Необхідність володіння медіатором такими вміннями підвищується в умовах виникнення комунікативних збоїв та необхідності подолання комунікативних бар'єрів, у т.ч. соціокультурних, які можуть бути наслідком соціокультурних відмінностей у ціннісному світогляді та ін. (Council of Europe, 2016: 48-59; North \& Coodier, 2017; North \& Piccardo, 2016). При цьому наголошується, що дослідження меді- 
ації як виду комунікативної діяльності логічно здійснювати 3 позиції соціоконструктивістського або соціокультурного підходів, що беруть витоки в культурно-історичній концепції Л. Виготського (North, \& Piccardo, 2016: 4). Враховуючи це, в заключному документі «CEFR Companion Volume with New Descriptors (Provisional Edition) Communicative language» у 2017 році прийнято розширену дефініцію медіації як комунікативної діяльності: «In mediation, the user/learner acts as a social agent who creates bridges and helps to construct or convey meaning, sometimes within the same language, sometimes from one language to another (cross-linguistic mediation). The focus is on the role of language in processes like creating the space and conditions for communicating and/or learning, collaborating to construct new meaning, encouraging others to construct or understand new meaning, and passing on new information in an appropriate form. The context can be social, pedagogic, cultural, linguistic or professional... in mediation... A person who engages in mediation activity needs to have a well-developed emotional intelligence, or an openness to develop it, in order to have sufficient empathy for the viewpoints and emotional states of other participants in the communicative situation. The term mediation is also used to describe a social and cultural process of creating conditions for communication and cooperation ...» (Council of Europe, 2017: 99).

У мультикультурному світі медіатор стає «медіатором культур», тобто людиною, що пов'язана 3 процесом передачі концептуальної та культурологічної інформації, релевантної для даної ситуації спілкування. На думку науковця Р. Тафта, медіатор має бути бікультурною особистістю та володіти сукупністю таких знань, умінь та навичок (Тафт, 1981: 53, 73): знанням про культуру відповідної мовної групи, народу, що охоплює історію, фольклор, традиції, звичаї, цінності тощо; навичками вербального та невербального спілкування; технічними навичками, що передбачає комп'ютерну грамотність тощо; соціальними навичками, що охоплюють знання правил, норм, які регулюють соціальні відносини в представленому суспільстві, емоційну компетентність, володіння навичками самоконтролю. Окрім володіння наведеними навичками, медіатор має бути гнучким в інтеркультурному аспекті. Слід також ураховувати, що розвиток конструктивної взаємодії може ускладнюватися 3 причини приналежності комунікантів до різних лінгвокультур, тому дослідниками цієї галузи дискурс міжкультурної медіації визначається також як менеджмент розбіжностей у контексті різних культурних ідентич- ностей, конвенціональних норм та соціокультурних цінностей учасників медіації - представників різних лінгвокультур 3 урахуванням специфіки їхніх комунікативно-прагматичних компетенцій. Як центроформуючий фактор у полі конфліктного спілкування комунікантів різних національностей слід виокремити фактор медіатора, в ролі якого може виступати як група посередників - колективна особа, так і конкретна особа персональний дискурсивний посередник. 3 боку всіх учасників дискурсу міжкультурної медіації в процесі контактного спілкування здійснюється референція до об'єктів дійсності, що є в даному випадку джерелом спору. У цьому зв'язку слід зазначити, що в умовах монокультурної взаємодії йдеться про ідентифікуючий тип інтенціональної референції, тобто коли обидві сторони перемовного процесу є потенційно більш готовими до відновлення відносин інтерсуб'єктивності як факту прояву комунікативного співробітництва завдяки тому, що спираються на спільний пресупозиційний фонд. Якщо медіативний процес передбачає участь представників різних культур, то для одного 3 них смисли референції можуть залишитися незрозумілими, ціннісно нерелевантними. 3 цієї причини особливого значення набуває техніка синхронізації референції з боку встановлення або підтримки інтерсуб' єктності як спільної колективної дії суб'єктів конфлікту. При цьому знакове регулювання медіатором дискурсивної поведінки учасників медіативного процесу можна розглядати через уведення в поле значень адресата нових значень, перебудову поля значень та зміну смислового поля.

Основною місією медіатора $є$ налагодження міжкультурної комунікації, особистісної комунікації та взаєморозуміння. Медіатор має проявляти толерантність та повагу до іноетнічних традицій, звичаїв, цінностей тощо (Смислова, 2011: 45).

Використання обох вищезгаданих моделей дозволяє підготувати фахівців, які можуть бути посередниками між представниками рідної та іноземної культури під час медіативного процесу, здійснюючи усну та письмову комунікацію. Слід також зазначити, що такі фахівці мають володіти знаннями про національні професійні реалії, вміти визначати їх місце та значущість в ієрархії цінностей у глобальному співтоваристві. Отже, за доцільне маємо розглянути поняття «глокалізація», яке тісно пов'язане із процесом формування медіативної компетентності засобами професійної іноземної мови.

За Р. Робертсоном, глокалізація трактується як трансформація глобалізаційних процесів з ура- 
хуванням локальної специфіки та охоплює не тільки інтернаціональне та транснаціональне, але й також транскультурне та транслокальне. 3 урахуванням глокального підходу в процесі формування медіативної компетентності на заняття 3 іноземної мови мають використовуватися етнорегіональні матеріали, сталі елементи культури, що сприяють розкриттю змісту етнокультурних традицій, уведенню актуального соціокультурного матеріалу. За глокального підходу відбувається реалізація ідеї діалогу та полілогу культур, яка відображатиме новий тип мислення студентів трансглокальне сприйняття та розуміння оточуючого світу. Завдяки цьому підходу в майбутніх фахівців з економіки формуються необхідні вміння висловлювати власну точку зору, коректно висловлювати оціночні судження, толерантно ставитися до думки співрозмовника, вміння з аналізу, зіставлення та інтерпретації фактів, суджень, думок, критичне сприйняття інформації, встановлення причинно-наслідкових зв'язків (Чернишенко, 2014).

У процесі формування міжкультурної медіативної компетентності фахівців на заняттях з іноземної мови за професійним спрямуванням студенти мають набути досвід побудови взаємовідносин на засадах міжкультурної толерантності через виконування відповідних навчальних завдань, оволодіти знаннями культури та традицій різних країн, опанувати відповідні вербальні та невербальні засоби спілкування, навички побудови конструктивного діалогу, врегулювання конфліктних ситуацій, етичних норм ділового спілкування, ведення перемовин, а також норм поведінки під час співпраці з іноземними партнерами, усвідомити культурно зумовлені відмінності, що мають вплив на комунікацію між представниками різних культур; ознайомитися з особливостями ведення професійної комунікації з іноземними партнерами тощо.

Опанування досвіду побудови ділових відносин на засадах взаємоповаги повинно відбуватися не тільки на репродуктивному рівні через використання набутих знань, умінь і навичок за певним алгоритмом, а й на творчому рівні через вирішення нових, нестандартних професійних ситуацій. Досвід творчої діяльності дозволить фахівцю самостійно застосовувати знання та навички на практиці, виробляти ціннісне ставлення до своєї професії.

3 метою ефективного формування медіативної компетентності доцільним $є$ використання активних та інтерактивних (дискусії, диспути, метод кейса, рольові ігри тощо) методів навчання, а також методів проблемного викладення навчаль- ного матеріалу, частково-пошукових, дослідницьких і творчих.

Розглянемо приклади дидактичних засобів формування зазначеної компетентності на заняттях із професійно-орієнтованої англійської мови 3 урахуванням міжкультурного аспекту:

1. Listen first, talk second. You should listen to what the other person is saying before defending your own position. They might say something that changes your mind (1).

Watch the video at https://www.youtube.com/ watch? $\mathrm{v}=\mathrm{t} 2 \mathrm{z} 9 \mathrm{mdX} 1 \mathrm{j} 4 \mathrm{~A}$ (Improve Your Listening Skills with Active Listening 2: 39).

a. What pieces of advice would you give to improve your listening skills? Make a list and discuss it with your partners.

2. Watch the video at https://www.youtube.com/ watch? $=0$ iC4TyWp2VQ (Cross-Cultural Communication and Conflicts 10: 49).

3. Analyse the following situations and try to decide:

- What cultural factors, in your opinion, are playing an important role in the case?

- What could be done to improve the situation which is described below?

a. You are responsible for a project team with team members in India, Japan, Germany, Britain, China and the United States. You have spent a lot of time planning the project and are disappointed that you don't seem to be getting as much feedback as you had expected from the other team members.

To try to get the others on board you have started to have a weekly telephone conference to hear some input from them. This has not really helped much either, as it never seems possible to get everyone on the team to participate, and, even if they are on the line, they don't say anything or they just agree to the particular suggestions that you make to them.

b. Your international organization has a complex matrix structure, with many people working most of the time on projects and reporting to a project leader rather than to their disciplinary line manager.

You have noticed that this system seems to work extremely well in western countries, but is less successful in central and eastern Europe. You have the feeling that the local project managers aren't able to get the support needed from their teams in those countries. You are uncertain what to do in order to improve the situation.

c. You are the global sales manager of a company with operations in many countries worldwide. One of your most important tasks is to collect the sales figures from the regions and present them to top management. Although this sounds simple, you fre- 
quently have problems getting data from the regional sales teams, and, if you do get the data, you sometimes wonder how accurate it is.

You are very concerned about this, as this data is the basis of all business decisions and needs to be accurate and delivered on time. This requirement is also firmly written into the job descriptions of all the regional sales managers.

- Define the reasons of the conflicts.

- What mistakes have been made in communicating with colleagues? How can these conflicts be resolved? (5)

4. «Pebble in the Shoe» (модифіковано на основі методів, запропонованих науковцем Л. Шустовою). Each person has his vulnerability, his own problem, a «pebble in the shoe», which prevents from effective realization of the professional skills. Think about something in your character that doesn't allow you to express tolerant attitude to foreign business partners. Discuss the results in the group.

5. «Pearl in the shell» (модифіковано на основі методів, запропонованих науковцем Л. Шустовою). Each person has a number of inherent individual qualities and virtues that enable him or her to solve complex professional tasks. Try to determine your personal advantages that can promote effective economic cooperation with foreign business partners on the basis of cross-cultural tolerance. Discuss the results in the group (Шустова, 2006).

6. Imagine that employees in your company have a conflict over the launch of new product. Try to find the decision how you resolve this problem. Discuss it in the group.

7. Role-play. Student 1. Imagine that your company is getting ready for the merger with foreign company that wants to cut the expenses for training personnel. Your company doesn't support this idea. Negotiate this problem with Student 2. Think through the following points before you start negotiating:

a. Goals;

b. Alternatives;

c. Relationships (Will there be any hidden issues that may influence the negotiation? How will you handle these?);

d. Expected outcomes;

e. The consequences; f. Power (Who controls resources? Who stands to lose the most if agreement isn't reached? What power does the other person have to deliver what you hope for?);

g. Possible solutions.

Student 2. Imagine that your company is getting ready for the merger with foreign company and you want to reduce the expenses for training personnel. Your future partners don't support this idea. Negotiate this problem with Student 1. Think about the points listed above;

8. Discuss the following questions:

a. What types of conflict do you know?

b. What ways of resolving the conflict do you know?

c. What is the essence of the Interest-Based Relational Approach to resolving the conflicts?

d. What steps should be followed for resolving the conflict?

e. What is the essence of win-win negotiations?

f. How can listening skills be improved?

g. If you go to the foreign country, what information should you know about cultural traditions of your business partners?

h. What, do you think, has the crucial role in building effective relationship with foreign business partners?

i. Is there any dependence between the level of cross-cultural tolerance of the country and conflicts?

j. What, in your opinion, are the most common mistakes when building relationship with foreign business partners?

$k$. Do you think it is reasonable for the company to invest money in intercultural training?

Висновки. Отже, в статті проаналізовано міжкультурний аспект формування медіативної компетентності в процесі вивчення професійно-орієнтованої іноземної мови в закладах вищої освіти, виокремлено його складники та надано приклади дидактичних засобів формування зазначеної якості на заняттях із професійно-орієнтованої англійської мови 3 урахуванням міжкультурного аспекту. До сфери подальшого наукового пошуку входить детальний аналіз медіативної культури як невід'ємної частини міжкультурної підготовки майбутніх фахівців.

\section{СПИСОК ВИКОРИСТАНИХ ДЖЕРЕЛ}

1. Conflict Resolution. URL: https://www.mindtools.com/pages/article/newLDR_81.htm

2. Council of Europe. Common European Framework of Reference: Learning, teaching, assessment. Cambridge, 2001.

3. Council of Europe. CEFR Illustrative Descriptors. Extended Version 2016. Pilot version for consultation. Strasbourg : Language Policy Unit, 2016.

4. Council of Europe. CEFR Companion Volume with New Descriptors (Provisional Edition). Communicative language. Education Policy Division, Education Department, 2017. URL: https://rm.coe.int/common-european-framework-ofreference-for-languages-learning-teaching/168074a4e2 
5. Intercultural Communication (2009). Business Spotlite. BSL Media, 6. URL: https://business-spotlight.ihned.cz/ c1-39228430-6-2009-magazine-content-online

6. North B., Coodier T. Recent Updates to the CEFR and Relevance for Classroom Practitioners. URL: https://www. slideshare.net/eaquals/ brian-north-recent-updates-to-cefr-riga-2017final (дата звернення: 25.11.17).

7. North B., Piccardo E. Developing illustrative descriptors of aspects of mediation for the Common European Framework of reference (CEFR), 2016. URL: https://rm.coe.int/developing-illustrative-descriptors-of-aspects-of-mеd (дата звернення: 25.11.17).

8. Смислова О. До питання професійної підготовки лінгвістичного медіатора. Теоретичні питання культури, освіти та виховання. Київ : КНЛУ, 2011. С. 44-47.

9. Taft R. The Role and Personality of the Mediator/S. Bochner (ed.) The Mediating Person : Bridges Between Cultures, 1981. Cambridge MA : Schenkman. P. 53-88.

10. Чернышенко А. Г. Специфика дискурсивных стратегий. Стратегии дискурса медиации. Профессиональная коммуникация : актуальные вопросы лингвистики и методики. Пятигорск : ПГЛУ, 2014. 252 с.

11. Шустова Л. П. Воспитание толерантности - приемы для индивидуальной работы. Классный руководитель. 2006. № 4. C. 77-80.

\section{REFERENCES}

1. Conflict Resolution. Retrieved from: https://www.mindtools. com/pages/article/newLDR_81.htm [in English]

2. Council of Europe. Common European Framework of Reference: Learning, teaching, assessment. Cambridge, 2001. [in English]

3. Council of Europe. CEFR Illustrative Descriptors. Extended Version 2016. Pilot version for consultation. - Strasbourg: Language Policy Unit, 2016. [in English]

4. Council of Europe. CEFR Companion Volume with New Descriptors (Provisional Edition). Communicative language. Education Policy Division, Education Department, 2017. URL: https://rm.coe.int/common-european-framework-ofreference-for-languages-learning-teaching/168074a4e2 [in English]

5. Intercultural Communication (2009). Business Spotlite. BSL Media, 6. Retrieved from: https://business-spotlight. ihned.cz/c1-39228430-6-2009-magazine-content-online [in English]

6. North B., Coodier T. Recent Updates to the CEFR and Relevance for Classroom Practitioners. / B. North B., Coodier T. URL: https://www.slideshare.net/eaquals/ brian-north-recent-updates-to-cefr-riga-2017final [in English]

7. North B., Piccardo E. Developing illustrative descriptors of aspects of mediation for the Common European Framework of reference (CEFR), 2016. URL: https://rm. coe.int/ developing-illustrative-descriptors-of-aspects-of-med [in English]

8. Smyslova O. Do pytannya profesiynoi pidgotovki lingvistychnogo mediatora [About professional Education of a linguistic Mediator]. Teoretychni pytannya. KNLU. Kyiv. 2011. P. 44-47. [in Ukranian]

9. Taft R. The Role and Personality of the Mediator / S. Bochner (ed.) The Mediating Person : Bridges Between Cultures. Cambridge, MA : Schenkman. 1981. P. 53- 88. [in English]

10. Chernyshenko A. G. Spetsifica diskursivnih strategiy. Strategii diskursa mediatsii [Specific of Discourse Strategies. Strategies of Mediation Discourse]. Professionalnaya komunikatnie voprosi lingvistiki i metodiki. Pyatigorsk : PGLU. 2014. 252 p. [in Russian]

11. Shustova L. P. Vospitanie tolerantnosti - priyomi dla individualnoy raboty [Tolerance Education - Tools for Individual Work]. Klassniy rukovoditel.2006. № 4. C. 77-80 [in Russian] 